\title{
Determinants of Democracy
}

\section{Citation}

Barro, Robert J. 1999. Determinants of democracy. Journal of Political Economy 107(S6): 158-183.

\section{Published Version}

doi:10.1086/250107

\section{Permanent link}

http://nrs.harvard.edu/urn-3:HUL.InstRepos:3451297

\section{Terms of Use}

This article was downloaded from Harvard University's DASH repository, and is made available under the terms and conditions applicable to Other Posted Material, as set forth at http:// nrs.harvard.edu/urn-3:HUL.InstRepos:dash.current.terms-of-use\#LAA

\section{Share Your Story}

The Harvard community has made this article openly available.

Please share how this access benefits you. Submit a story.

Accessibility 


\title{
Determinants of Democracy
}

\author{
Robert J. Barro
}

Harvard University

\begin{abstract}
A panel study of over 100 countries from 1960 to 1995 finds that improvements in the standard of living predict increases in democracy, as measured by a subjective indicator of electoral rights. The propensity for democracy rises with per capita GDP, primary schooling, and a smaller gap between male and female primary attainment. For a given standard of living, democracy tends to fall with urbanization and with a greater reliance on natural resources. Democracy has little relation to country size but rises with the middle-class share of income. The apparently strong relation of democracy to colonial heritage mostly disappears when the economic variables are held constant. Similarly, the allowance for these economic variables weakens the interplay between democracy and religious affiliation. However, negative effects from Muslim and non-religious affiliations remain intact.
\end{abstract}

An expansion of political freedom-more democracy-has opposing effects on economic growth. On the positive side, democratic institutions provide a check on governmental power and thereby limit the potential of public officials to amass personal wealth and to carry out unpopular policies. But on the negative side, more democracy encourages rich-to-poor redistributions of income and may enhance the power of interest groups. Consequently, the net effect of democracy on growth is uncertain. (See Sirowy and Inkeles [1990] and Przeworski and Limongi [1993] for surveys of theories that relate democracy to economic growth.)

My previous cross-country empirical work, as summarized in Barro (1997), finds a nonlinear effect of democracy on growth. Growth is initially increasing in an index of electoral rights, but the relation 
turns negative once a moderate amount of rights has been attained. One way to interpret these results is that, in the worst dictatorships, an increase in democracy tends to stimulate growth because the benefit from limitations on governmental power is the key matter. But in places that have already achieved a moderate amount of democracy, a further increase impairs growth because the dominant effect comes from the intensified concern with social programs that redistribute resources.

The present analysis focuses on the reverse channel, that is, the impact of economic development on a country's propensity to experience democracy. A common view since Lipset's (1959) research is that prosperity stimulates democracy; this idea is often called the Lipset hypothesis. Lipset credits the idea to Aristotle: "From Aristotle down to the present, men have argued that only in a wealthy society in which relatively few citizens lived in real poverty could a situation exist in which the mass of the population could intelligently participate in politics and could develop the self-restraint necessary to avoid succumbing to the appeals of irresponsible demagogues" (p. 75). (For a statement of Aristotle's views, see Aristotle [1932, book 6].)

Theoretical models of the effect of economic conditions on the extent of democracy are not well developed. Lipset (1959, pp. 8384) emphasized increased education and an enlarged middle class as key elements, and he also stressed Tocqueville's (1835) idea that private organizations and institutions are important as checks on centralized government power. This point has been extended by Putnam (1993), who argues that the propensity for civic activity is the key underpinning of good government in the regions of Italy. For Huber, Rueschemeyer, and Stephens (1993, pp. 74-75), the crucial concept is that capitalist development lowers the power of the landlord class and raises the power and ability to organize of the working and middle classes.

In some models, an autocrat would voluntarily relinquish some authority-for example, by establishing a constitution, empowering a legislature, expanding voting rights, and extending civil libertiesin order to deter revolution and to encourage the private sector to invest (and, thereby, to expand the pie that the government can tax). Boone (1996) develops a model along these lines and determines the equilibrium amount of freedom by considering the net benefits of oppression to potential rulers. However, in this type of setting, most effects turn out to be ambiguous. For example, an increase in human capital raises the people's ability to resist oppression but also raises the ruler's benefits from subjugating them. 
Similarly, a rise in urbanization makes it easier for people to meet and communicate-which presumably makes them harder to suppress-but also makes it easier for an autocrat to monitor and control activities.

Despite the lack of clear predictions from theoretical models, the cross-country evidence examined in the present study confirms that the Lipset/Aristotle hypothesis is a strong empirical regularity. In particular, increases in various measures of the standard of living forecast a gradual rise in democracy. In contrast, democracies that arise without prior economic development-sometimes because they are imposed by former colonial powers or international organizations-tend not to last. Given the strength of this empirical regularity, one would think that clear-cut theoretical analyses ought also to be attainable. (This seems to be a case in which the analysis works better in practice than in theory.)

\section{The Measure of Democracy}

The main definition of democracy in the present study is a narrow one that focuses on the role of elections. This concept accords with the one adopted by Huntington (1991, p. 6): "The central procedure of democracy is the selection of leaders through competitive elections by the people they govern." His inspiration for this procedural definition of democracy comes from Schumpeter (1947, p. 269): "The democratic method is that institutional arrangement for arriving at political decisions in which individuals acquire the power to decide by means of a competitive struggle for the people's vote."

More specifically, I use as a measure of democracy the indicator of electoral rights compiled by Gastil (1982-83 and subsequent issues) and his followers at Freedom House from 1972 to 1995. A related variable from Bollen (1990) is used for 1960 and 1965. ${ }^{1}$ The Freedom House concept of electoral rights uses the following basic definition: "Political rights are rights to participate meaningfully in the political process. In a democracy this means the right of all adults to vote and compete for public office, and for elected representatives

\footnotetext{
${ }^{1}$ See Gastil (1991) for a discussion of the methods that underlie his data series. Inkeles (1991) provides an overview of measurement issues on democracy. He finds a "high degree of agreement produced by the classification of nations as democratic or not, even when democracy is measured in somewhat different ways by different analysts" (p. x). Bollen (1990) suggests that his measures are reasonably comparable to Gastil's. It is difficult to check comparability directly because the two series do not overlap in time. Moreover, many countries-especially those in Africa-clearly experienced major declines in the extent of democracy from the 1960s to the 1970s. Thus no direct inference about comparability can be made from the higher average of Bollen's figures for the 1960s than for Gastil's numbers for the 1970s.
} 
to have a decisive vote on public policies" (Gastil 1986-87, p. 7). In addition to the basic definition, the classification scheme rates countries (somewhat impressionistically) as less democratic if minority parties have little influence on policy.

Freedom House applied the concept of electoral rights on a subjective basis to classify countries annually into seven categories; group one is the highest level of rights and group seven is the lowest. The classification was made by Gastil and his associates and followers on the basis of an array of published and unpublished information about each country. The original ranking from one to seven was converted here to a scale from zero to one, where zero corresponds to the fewest rights (Gastil's rank seven) and one to the most rights (Gastil's rank one). The scale from zero to one corresponds to the system used by Bollen.

To fix ideas on the meaning of the zero to one scale, note first that the United States and most other OECD countries in recent years received the value 1.0, thereby being designated as full representative democracies. Dictatorships that received the value 0.0 in 1995 included Indonesia, Iraq, Syria, Zaire, and several other countries in Africa. Places that were rated at 0.5 - halfway between dictatorship and democracy-included Colombia, Dominican Republic, Ghana, Guatemala, Malaysia, Mexico, Nicaragua, Paraguay, Senegal, and Sri Lanka.

The solid line in figure 1 shows the time path of the unweighted average of the electoral rights index for the countries that I am considering for the years 1960, 1965, and 1972-95. The number of countries covered rises from 99 in 1960 to 109 in 1965 and 138 from 1972 to $1995 .^{2}$ The figure shows that the mean of the index peaked at 0.66 in 1960 , fell to a low point of 0.44 in 1975 , and rose subsequently to 0.59 in 1995 .

Figure 1 also demonstrates that the main source of the decline in electoral rights after 1960 was the experience in sub-Saharan Africa. The dotted line shows that the average of the indicator in subSaharan Africa peaked at 0.58 in 1960 (26 countries) and then (for 43 countries) fell to low points of 0.19 in 1977 and 0.18 in 1989 before rising to 0.40 in 1995 . This pattern emerges because many of the African countries began with ostensibly democratic institutions when they became independent in the early 1960s, but most evolved into one-party dictatorships by the early 1970s. (See Bollen [1990] for further discussion.) The democratization in Africa since 1989 has been substantial; whether it will be sustained is not yet known.

\footnotetext{
${ }^{2}$ The Gastil data cover more than 138 countries, but my sample is more limited to reflect the availability of other data.
} 


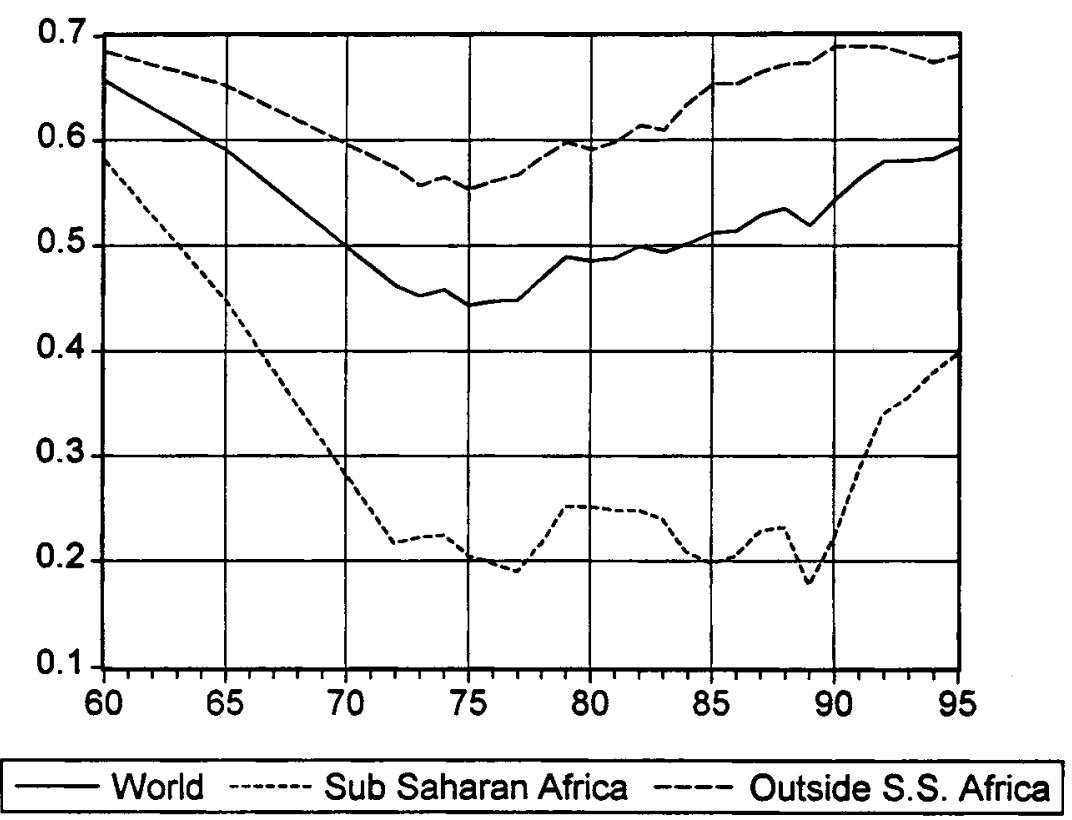

FIG. 1.-Democracy in the world, 1960-95

For countries outside of sub-Saharan Africa, the dashed line in figure 1 shows that the average of the electoral rights index fell from 0.68 in 1960 (73 countries) to 0.55 in 1975 (95 countries). It then returned to 0.68 in 1995. Thus, outside of sub-Saharan Africa, the democratization since the mid 1970s has been sufficient to reattain the average value for 1960 .

Some of the analysis also uses the Freedom House indicator of civil liberties. The definition here is "civil liberties are rights to free expression, to organize or demonstrate, as well as rights to a degree of autonomy such as is provided by freedom of religion, education, travel, and other personal rights" (Gastil 1986-87, p. 7). Otherwise, the subjective approach is the same as the one used for the electoral rights indicator. The original scale for the civil liberties index from one to seven has again been converted to zero to one, where zero represents the fewest civil liberties and one the most. In practice, as observed by Inkeles (1991), the indicator for civil liberties is extremely highly correlated with that for electoral rights. This high degree of correlation does not apply if the indexes of electoral rights and civil liberties are compared with measures of property rights and legal structure, such as Knack and Keefer's (1995) indicator for maintenance of the rule of law, which is used in the subsequent analysis. 


\section{Framework for the Determination of Democracy}

Inspection of the cross-country data suggests that countries at low levels of economic development typically do not sustain democracy. For example, the political freedoms installed in most of the newly independent African states in the early 1960s did not tend to last. Conversely, nondemocratic places that experience substantial economic development tend to become more dramatic. Examples include Chile, South Korea, Taiwan, Spain, and Portugal. Moreover, the countries of central and eastern Europe-which have been reasonably advanced economically for some time, especially in terms of education-eventually became more democratic. Thus a casual view of the data seems to support the Lipset/Aristotle hypothesis.

To assess this hypothesis formally, I consider systems of the form

$$
\begin{aligned}
\operatorname{DEMOC}_{i t}= & a_{0 t}+a_{1} \text { DEMOC }_{i, t-T} \\
& +a_{2} \text { DEMOC }_{i, t-2 T}+a_{3} \mathbf{Z}_{i, t-T}+u_{i t},
\end{aligned}
$$

where $i$ is the country; $t$ is the time period; $T$ is a time lag, usually taken to be five years; DEMOC is the indicator for democracy-electoral rights or civil liberties; $\mathbf{Z}$ is a vector of variables, such as per capita gross domestic product and education, that influence the extent of democracy; and $u$ is an error term. The idea in equation (1) is that if $a_{1}>0, a_{2}>0$, and $0<a_{1}+a_{2}<1$, then the extent of democracy in a country converges gradually over time toward a (moving) target that is determined by the $\mathbf{Z}$ variables. ${ }^{3}$ In practice, the $\mathbf{Z}$ variables are themselves highly persistent over time.

Operationally, I use a panel setup in which the dependent variable, DEMOC $_{i t}$, is observed at most six times for each country: 1972, 1975, 1980, 1985, 1990, and 1995. (The year 1972 is the initial date of the Freedom House sample.) The variables $\mathbf{Z}_{i, t-T}$ refer to observations roughly five years prior to these dates, and $\mathrm{DEMOC}_{i, t-T}$ and DEMOC $_{i, t-2 T}$ refer, respectively, to (approximately) five- and 10-year lags of the dependent variable. ${ }^{4}$ (The values for DEMOC $_{t-T}$ pertain to $1965,1972,1975$, and so on.) The system includes a separate con-

\footnotetext{
${ }^{3}$ The democracy indicators take on only seven discrete values between zero and one, but the linear specification on the right-hand side does not take this pattern into account. In practice, the most negative fitted value for electoral rights turned out be -0.02 for Indonesia in 1972, and the highest fitted value was 1.09 for the United States in 1995. Some improvement might result from the adoption of a nonlinear specification in which the dependent variable was constrained to the interval $(0,1)$.

${ }^{4}$ The empirical results turn out to be virtually the same if contemporaneous values of the $\mathbf{Z}$ variables are entered into eq. (1) (i.e., if the lag $T$ is set to zero), but lagged values of the $\mathbf{Z}$ variables and the lags of democracy are used as instruments.
} 
stant term, $a_{0 t}$, for each date. The other coefficients $\left(a_{1}, a_{2}\right.$, and $\left.a_{3}\right)$ are constrained to be the same for each time period.

The panel estimation is carried out by the seemingly unrelated regression (SUR) method. In this approach, the error term, $u_{i t}$, for country $i$ at time $t$ is allowed to be correlated with the term $u_{i^{\prime}}$ for the same country at different dates, $t^{\prime}$. The variance of $u_{i t}$ varies with $t$ but not with $i$ (so that countries are weighted equally in the estimation). In practice, the estimated correlations of the error terms across the time periods turn out to be small, and the results are similar if weighted least squares is used instead of the SUR method. The results are also similar with ordinary least squares (so that the equations for all time periods are weighted equally).

\section{Regression Results for Democracy: Standard of Living and Related Variables}

The basic regression results for electoral rights are in column 1 of table 1 . This system contains the five-year and 10-year lags of the dependent variable as regressors. The explanatory variables also include the log of real per capita $\mathrm{GDP}^{5}$ and measures of educational attainment. These indicators are observed roughly five years prior to the dependent variable. The schooling figures that turn out to have the most explanatory power are the average years of attainment at the primary level for persons aged 25 and over and the gap in average years of primary attainment between males and females aged 25 and over. ${ }^{6}$

A dummy for oil-exporting countries, as designated by the International Monetary Fund (IMF), ${ }^{7}$ is also included as a rough adjustment of GDP for the contribution of natural resources. The idea here is that the income generated from natural resources such as oil may create less pressure for democratization than income associated with the accumulation of human and physical capital.

The specification includes some other possible influences on democracy that have been proposed in the political science literature that began with Lipset (1959); see Lipset, Seong, and Torres (1993)

\footnotetext{
${ }^{5}$ The GDP data are taken from Summers and Heston $(1991,1995)$. Descriptions of these and other variables are in the Barro-Lee data set, which is available on the Internet from the World Bank (worldbank.org/html/prdmg/grthweb/growtht.htm).

${ }^{6}$ The data on years of schooling are updated values described in Barro and Lee (1996).

${ }^{7}$ The IMF definition includes countries whose net oil exports represent a minimum of two-thirds of total exports and are at least equivalent to approximately 1 percent of world exports of oil. A definition based on OPEC membership would add Ecuador and subtract Bahrain and Oman.
} 
TABLE 1

Regressions for Electoral Rights and Civil Liberties Indexes

\begin{tabular}{|c|c|c|}
\hline \multirow[b]{2}{*}{ INDEPENDENT VARIABLE } & \multicolumn{2}{|c|}{ DePENDENT Variable } \\
\hline & $\begin{array}{l}\text { Electoral Rights } \\
\text { (1) }\end{array}$ & $\begin{array}{l}\text { Civil Liberties } \\
\text { (2) }\end{array}$ \\
\hline 5-year lag of dependent variable & $\begin{array}{l}.608 \\
(.041)\end{array}$ & $\begin{array}{l}.536 \\
(.041)\end{array}$ \\
\hline 10-year lag of dependent variable & $\begin{array}{l}.102 \\
(.040)\end{array}$ & $\begin{array}{l}.148 \\
(.039)\end{array}$ \\
\hline $\log (\mathrm{GDP})$ & $\begin{array}{l}.058 \\
(.016)\end{array}$ & $\begin{array}{l}.054 \\
(.014)\end{array}$ \\
\hline Years of primary schooling & $\begin{array}{l}.0134 \\
(.0059)\end{array}$ & $\begin{array}{l}.0143 \\
(.0051)\end{array}$ \\
\hline $\begin{array}{l}\text { Gap between male and female primary } \\
\text { schooling }\end{array}$ & $\begin{aligned}-.047 \\
(.013)\end{aligned}$ & $\begin{aligned}-.043 \\
(.011)\end{aligned}$ \\
\hline Urbanization rate & $\begin{aligned}-.095 \\
(.048)\end{aligned}$ & $\begin{aligned}-.075 \\
(.041)\end{aligned}$ \\
\hline $\log$ (population) & $\begin{array}{l}.0080 \\
(.0044)\end{array}$ & $\begin{array}{l}.0012 \\
(.0038)\end{array}$ \\
\hline Oil country dummy & $\begin{array}{l}-.094 \\
(.031)\end{array}$ & $\begin{array}{r}-.096 \\
(.027)\end{array}$ \\
\hline$R^{2}$ & $\begin{array}{l}.62, .76, .67 \\
.76, .76, .56\end{array}$ & $\begin{array}{l}.63, .81, .77 \\
.82, .75, .70\end{array}$ \\
\hline Observations & $\begin{array}{c}76,88,102 \\
102,103,100\end{array}$ & $\begin{array}{c}76,88,102 \\
102,103,100\end{array}$ \\
\hline
\end{tabular}

NotE.-The systems have six equations in which the dependent variables are the values of the electoral rights or civil liberties indexes for 1972, 1975, 1980, 1985, 1990, and 1995. The five-year lag refers to 1965 , 1972, 1975, etc. The 10-year lag refers to 1960, 1965, 1972, etc. The lagged values used for 1960 and 1965 (from Bollen [1990]) are the same in the two equations. The variables GDP (real per capita GDP), primary schooling (years of attainment for persons aged 25 and over at the primary level), the gap between male and female primary schooling, urbanization rate, and population refer to 1965,1970 , etc. The oil dummy equals one for countries designated as oil-exporting by the IMF and zero otherwise. Each system contains a different constant for each time period. The estimation, by the SUR technique, weights countries equally but allows for different error variances in each period and for correlation of these errors over the periods. Standard errors of the estimated coefficients are shown in parentheses. The $R^{2}$ values apply to each period individually.

and Lipset (1994) for discussions. The urbanization rate is often mentioned as a determinant of democracy, although the sign of this influence is not clear on theoretical grounds. Some observers argue that the rural population has limited ability to organize and is therefore easy for a dictator to suppress. But one could also argue that a less dense, rural population is harder for the central authority to monitor and control. The simple correlation between democracy and urbanization is strongly positive, but urbanization is also positively related to per capita GDP and the other measures of the standard of living that are included as regressors. In any event, the system includes as an explanatory variable the rate of urbanization observed five years prior to the dependent variable. ${ }^{8}$

${ }^{8}$ The figures on urbanization are the standard ones reported by the World Bank. 
The system also contains a measure of country size, the log of the five-year earlier level of population. It is, however, not apparent a priori whether a larger place is more or less likely to be democratic. One problem of interpretation is that country size is endogenous, as argued by Alesina and Spolaore (1995). Places that are too large to be manageable are likely to have split apart sometime in the past.

The first observation from column 1 of table 1 is that the estimated coefficient on the five-year lag of electoral rights is 0.61 (standard error 0.04$)$ and that on the 10 -year lag is $0.10(0.04)$. Thus democracy is highly persistent over time, but about 25 percent of the adjustment to a target position (determined by the other variables) occurs over five years, and nearly 70 percent occurs over 20 years. ${ }^{9}$

The results are broadly supportive of the idea that more prosperous places are more likely to be democratic. The estimated coefficients on $\log$ (per capita GDP) and the level of primary schooling are each significantly positive, $0.058(0.016)$ and $0.013(0.006)$, respectively. ${ }^{10}$ The first coefficient means that a doubling of per capita GDP (corresponding roughly to a one-standard-deviation change) would raise the electoral rights indicator by 0.04 in the short run and by 0.14 after the full lagged adjustment occurs. (Note that a shift by one Freedom House category corresponds to a change by 0.17 in the electoral rights index.) The second coefficient implies that an additional year of average school attainment (roughly a onestandard-deviation shift) raises the electoral rights indicator by 0.01 in the short run and 0.04 in the long run.

Democracy is also negatively and significantly related to the gap between male and female primary attainment, with an estimated coefficient of $-0.047(0.013)$. That is, more equal educational opportunity across the sexes raises the target level of democracy. Quantitatively, a rise in the male-female gap by 0.6 year (about a onestandard-deviation change) lowers the electoral rights index by 0.03 in the short run and 0.10 in the long run. One interpretation of this relation is that the spread between male and female attainment is a proxy for general inequality of schooling and income. However, the inclusion of explicit measures of educational and income inequality (discussed below) does not eliminate the explanatory power

\footnotetext{
${ }^{9}$ These results apply when the coefficients of the lagged dependent variables are interpreted in terms of a partial-adjustment model. Difficulties can arise here if the lagged dependent variables pick up effects of serially correlated error terms. However, at least when the lagged dependent variables are included as regressors, the residuals from the equations for electoral rights exhibit negligible correlations over time.

${ }^{10}$ School attainment of persons aged 25 and over has slightly more explanatory power than attainment of persons aged 15 and over.
} 
of the gap between male and female schooling. Perhaps more promising is the idea, reminiscent of Tocqueville (1835), that expanded educational opportunity for females goes along with a social structure that is generally more participatory and, hence, more receptive to democracy.

The oil country dummy is significantly negative, $-0.094(0.031)$, thereby indicating that the high level of per capita GDP associated with oil production does not have the usual positive linkage with democracy. The estimated coefficient implies that, in the long run, for given values of per capita GDP and the other explanatory variables, an oil country would have an electoral rights indicator that was lower by 0.32 (nearly two categories on the Freedom House scale).

It seems plausible that this result for oil would extend to natural resource availability more generally. To test this idea, I introduced the measure of natural resource intensity suggested by Sachs and Warner (1995), the ratio of primary-product exports to total exports. ${ }^{11}$ However, this variable is insignificant if added to the system shown in column 1 of table $1,-0.022$ (0.033), and the oil dummy remains significant, $-0.090(0.035)$. One problem with the export ratio variable is that it reflects a country's choices on which production activities to focus. Possibly a better measure of exogenous natural resource availability would outperform the oil dummy.

The estimated coefficient of the urbanization rate is negative and marginally significant, $-0.095(0.048)$. Thus once indicators of the standard of living are held constant, the association between urbanization and democracy switches sign and becomes negative. This result means that, for a given standard of living, it is not true that more rural places are less likely to be democratic.

The estimated coefficient on the log of population is positive and marginally significant, $0.0080(0.0044) .{ }^{12}$ Thus there is some indication that larger places are more likely to be democratic. However, as mentioned before, this result might reflect the endogeneity of country size.

The system shown in column 1 of table 1 allows for different intercepts in each of the equations, that is, for 1972, 1975, and so on. The estimated coefficient for each date-expressed as a deviation from the (unweighted) average intercept-is shown in column 1 of table 2. Column 2 of the table shows the unweighted mean of the electoral rights index at each date for the observations that are included in the regression sample.

\footnotetext{
${ }^{11}$ The value for 1970 enters into the first two equations, that for 1975 in the next two, and that for 1985 in the last two.

${ }^{12}$ A country's land area is insignificant if it is added to the regressions as another indicator of country size.
} 
TABLE 2

Variations in Democracy over Time

\begin{tabular}{lcc}
\hline \hline & $\begin{array}{c}\text { Estimated Constant Term } \\
\text { (Relative to Average) } \\
\text { Year }\end{array}$ & $\begin{array}{c}\text { Sample Mean of } \\
\text { Electoral Rights Index } \\
(2)\end{array}$ \\
\hline 1972 & $-.092(.024)$ & .54 \\
1975 & $-.047(.019)$ & .47 \\
1980 & $.043(.020)$ & .54 \\
1985 & $.035(.016)$ & .58 \\
1990 & $.023(.017)$ & .59 \\
1995 & $.038(.022)$ & .64 \\
\hline
\end{tabular}

Note. - Col. 1 shows the estimated constant term for the indicated date from the system in col. 1 of table 1 . The estimate is expressed as a deviation from the average of the constants over the six periods. The standard error of the coefficient estimate is shown in parentheses. The $p$-value for the hypothesis of equal constant terms is .0000 . Col. 2 is the mean of the electoral rights index over the sample included in the regression system for the indicated date.

The pattern of estimated intercepts suggests, in the language of Huntington (1991, p. 16), a wave whereby world democracy declined in the early 1970s and then rose in the early 1980s and again in the early 1990s. ${ }^{13}$ Note that these results apply for given values of the explanatory variables, which can also generate patterns in world democracy. For example, positive trends in per capita GDP and schooling would imply an upward trend in democracy. This result seems reasonable in a long-run global context because-when evaluated in terms of the Freedom House concept of electoral rightsthere have not been many democracies in the world until the twentieth century. Huntington (1991, p. 16) dates the first long wave of democratization as 1828-1926.

\section{Additional Influences on Democracy}

Table 3 considers other possible determinants of democracy, many of which have been proposed in the political science literature. These additional variables are entered one set at a time into the sixperiod regression system described in column 1 of table 1 .

\section{A. Health Indicators}

Regression 1 of table 3 adds a measure of health status-the log of life expectancy at birth-as another indicator of the standard of

${ }^{13}$ The pattern for the estimated intercepts in col. 1 of table 2 differs from that for the mean of the electoral rights index in col. 2 because of the dynamic relation between the dependent and independent variables. In particular, a permanent downward shift in the intercept would reduce democracy contemporaneously and would imply further declines in democracy in future periods. 
TABLE 3

Additional Determinants of Democracy

\begin{tabular}{lcl}
\hline \hline Independent Variable & Regression Coefficient \\
\hline 1. Log (life expectancy at birth) & $.129(.079)$ \\
2. Infant mortality rate & $-.44(.30)$ \\
3. Years of upper schooling & $-.008(.011)$ \\
Gap between male and female schooling & $.010(.024)$ \\
p-value & .76 & \\
4. Income inequality (Gini coefficient) & -.15 & $(.09)$ \\
5. Share of middle class in income & .26 & $(.15)$ \\
6. Educational inequality & -.008 & $(.046)$ \\
7. Ethnolinguistic fractionalization & $-.055(.028)$ \\
8. Rule-of-law index & $.031(.057)$ \\
9. Dummy for former colony & $-.018(.018)$ \\
10. Dummy for British colony & $-.031(.018)$ \\
Dummy for French colony & $-.020(.026)$ \\
Dummy for Spanish colony & $.007(.022)$ \\
Dummy for Portuguese colony & $.022(.048)$ \\
Dummy for other colony & $-.032(.034)$ \\
$p$-value & .33 \\
11. Muslim religion fraction & $-.093(.026)$ \\
Protestant religion fraction & $.006(.031)$ \\
Hindu religion fraction & $.049(.050)$ \\
Buddhist religion fraction & $.003(.047)$ \\
Miscellaneous eastern religion fraction & $-.081(.072)$ \\
Jewish religion fraction & $.035(.072)$ \\
Nonreligion fraction & $-.244(.089)$ \\
Other religion fraction & $-.103(.050)$ \\
$p$-value & .002 \\
\hline
\end{tabular}

NotE.-The indicated groups of explanatory variables are added, one at a time, to the system for the electoral rights index shown in col. 1 of table 1. (Regression 8 applies only to the three periods that start with the value of the electoral rights index for 1985 .)

Life expectancy at birth applies to $1965-69,1970-74$, etc. The infant mortality rate applies to 1965,1970 , etc. Upper schooling (from Barro and Lee [1996]) is the years of secondary and higher schooling for persons aged 25 and over in 1965, 1970, etc. The Gini coefficient for income inequality and the income share of the middle class (the three middle quintiles of income) are taken from Deininger and Squire (1996) and apply around 1970 in the first two equations, around 1980 in the next two equations, and around 1990 in the last two equations. A higher number for the Gini coefficient signifies more inequality. Educational inequality (from Barro and Lee [1996]) is the standard deviation of $\log (1+$ years of schooling) for the population aged 15 and over in 1965, 1970, etc. The ethnolinguistic fractionalization variable, which runs between zero and one, is a measure of heterogeneity of language and ethnicity. The number, observed once for each country, represents the probability that two randomly selected persons come from different groups; hence, a higher value signifies more heterogeneity. See Taylor and Hudson (1972, table 4.15) and Mauro (1995) for a discussion of these data. The rule-of-law index, discussed in Knack and Keefer (1995) and available for 1982-97 from Political Risk Services, is a subjective indicator of the extent of maintenance of the rule of law. The variable runs from zero to one, with a higher value indicating a more favorable environment.

Colony is a dummy for countries that are former or present colonies; any country that was independent before 1776 is designated as a noncolony. In regression 10, dummies for former British. French, Spanish, Portuguese, and other colonies are added together to the system from col. 1 of table 1. Colonial status is based on the most recent ruler; e.g., the Philippines is attributed to the United States rather than to Spain.

In regression 11, the fractions of the population affiliated with eight major religious groups are entered together into the system from col. 1 of table 1 . The left-out religion category is Catholic (including Eastern Orthodox). The religion data pertain to 1970 (in the first three equations) and 1980 (in the last three equations) and come from Barrett (1982). The Protestant group includes Anglicans, marginal Protestants (Jehovah's Witnesses, Mormons, and new-age cults), and cryto-Christians (secret believers in Christ not professing publicly). Eastern religions include Chinese folk religions, Shinto, Confucianism, and new-religions. The nonreligion category comprises those professing no religion and atheism. Other religions include Parsis, Spiritists, tribal religions, indigenous third-world Christians not of western importation, and Bahais. Jains and Sikhs are classed with Hindus. 
living. The estimated coefficient is positive but only marginally significant, 0.13 (0.08). With life expectancy included, the estimated coefficients of $\log$ (per capita GDP) and average years of primary schooling become less significant; the estimated coefficients are now $0.042(0.018)$ and $0.011(0.006)$, respectively. Thus it is difficult to sort out precisely the measures of standard of living that matter for democracy.

Similar results apply if the infant mortality rate is used as a measure of health status instead of life expectancy. Regression 2 of table 3 shows that the estimated coefficient of the infant mortality rate is $-0.44(0.30)$.

\section{B. Upper-Level Schooling}

Regression 3 in table 3 includes two additional schooling variables: the average years of schooling for persons aged 25 and over at the secondary and higher levels and the gap between male and female schooling for persons aged 25 and over at these levels. These variables are individually and jointly insignificant, as shown, whereas the estimated coefficients on primary schooling remain significant (0.014 [0.006] for years of schooling and -0.051 [0.016] for the gap between males and females). Hence, it appears to be early education that matters for democratization. Similar results apply to the determination of fertility rates and health status. However, as discussed in Barro (1997), rates of economic growth and investment relate far more to secondary and higher schooling than to primary education.

\section{Inequality of Income and Schooling}

Regression 4 of the table includes measures of income inequality, as gauged by Gini coefficients for the distribution of income. (A higher Gini coefficient signifies more inequality.) The data come from the careful compilation of information assembled by Deininger and Squire (1996). ${ }^{14}$ The underlying values were categorized as applying around 1970, 1980, and 1990 and were entered accordingly into the regression system (see the note to table 3 ). Because of the limited availability of data on income distribution, the inclusion of the Gini coefficient substantially reduces the number of observations: to 51 for the 1972 equation, 56 for 1975, 60 for 1980 and

\footnotetext{
${ }^{14}$ The regressions use their "high-quality" observations, which exclude observations based on incomplete geographical coverage or incomplete measures of income. I have added to their high-quality set some observations that Deininger and Squire excluded because of incomplete references to primary sources.
} 
1985, and 68 for 1990 and 1995. Within this truncated sample, the estimated coefficient on the Gini coefficient is negative but only marginally significant, $-0.15(0.09)$. However, in this reduced sample, some of the variables from the basic specification are also statistically insignificant: average years of primary schooling, the urbanization rate, the log of population, and the oil dummy. In any event, there is some indication that - for given measures of the standard of livinggreater income inequality predicts less democracy.

Many researchers stress a positive interaction between the size of the middle class and the extent of democracy. To check this relation, regression 5 of table 3 includes in the regression system the share of income accruing to the middle three quintiles (also compiled from Deininger and Squire [1996]). Because of the more severe limitation on data by quintile shares, this sample was even smaller than that for the Gini coefficient. (With the middle-class variable included, the numbers of observations for the various dates are 38, $40,51,51,65$, and 65.) The estimated coefficient of the middleclass share is positive, $0.26(0.15)$, but only marginally significant. However, in this sample, the estimated coefficients of average years of primary schooling, urbanization rate, the log of population, and the oil dummy are even less significant.

If the Gini coefficient is entered along with the middle-class share, then the estimated coefficients are $0.05(0.24)$ for the Gini (the "wrong" sign) and 0.32 (0.38) for the middle-class share. The middle-class variable also appears to be the more important indicator of inequality when it is entered jointly with the share of the lowest or highest quintile. Thus there is some evidence that the weight of the middle class is the aspect of inequality that matters most for democracy.

Another possibility is to use recently assembled data on educational attainment at seven levels to construct measures of schooling inequality (see n. 6 above). Regression 6 of table 3 uses as an independent variable the standard deviation of $\log (1+$ years of schooling $)^{15}$ for the population of both sexes aged 15 and over. This variable is observed for 1965, 1970, and so on. The estimated coefficient is close to zero, $-0.008(0.046)$. The estimated coefficients of primary schooling remain significant here: 0.013 (0.006) for average years of schooling and $-0.046(0.016)$ for the male-female gap. If the Gini coefficient for years of schooling is used as an alternative measure of educational inequality, then the findings are similar. Hence, these results indicate that the primary enrollment vari-

\footnotetext{
${ }^{15}$ The value one can be thought of as the effective years of educational human capital possessed by a person with no formal schooling.
} 
ables-and specifically the male-female gap-do not enter the regressions merely as proxies for educational inequality.

\section{Ethnolinguistic Fractionalization}

The population's degree of heterogeneity with respect to ethnicity, language, and culture may also matter for democracy. The usual idea is that more heterogeneity makes it more difficult to sustain democracy. A standard measure of a population's heterogeneity is its ethnolinguistic fractionalization, a measure of disparity of languages and ethnicity within a country. ${ }^{16}$ The variable runs between zero and one and is intended to measure the probability that two randomly chosen persons in a country come from different groups. Hence, zero is the most homogeneous, and one is the most heterogeneous.

Regression 7 of table 3 shows that the estimated coefficient of the fractionalization variable (observed once per country) is negative and marginally significant, $-0.055(0.028)$. Thus there is some indication that more ethnically diverse countries are less likely to sustain democracy.

One possibility is that ethnic diversity reduces democratic tendency by contributing to inequality. To test for this possibility, I included the middle-class share of income along with the fractionalization variable. The result was that the estimated coefficient of fractionalization was essentially zero, $0.002(0.036)$, whereas that on the middle-class share was $0.24(0.15)$, similar to that found in regression 5 of table 3 . It turns out, however, that the result does not reflect a high correlation between the fractionalization variable and the middle-class share (a correlation that is negative but small in magnitude) but rather the truncation of the sample. Within the limited sample for which data on the middle-class share are available, the estimated coefficient of the fractionalization variable is essentially zero even if the middle-class variable is omitted from the system.

\section{E. The Rule of Law}

Knack and Keefer (1995) discuss a variety of subjective country indexes of property rights and legal/ political structure that have been prepared for fee-paying international investors by International Country Risk Guide. The concepts covered include quality of the bureaucracy, political corruption, likelihood of government repudiation of contracts, risk of government expropriation, and overall mainte-

\footnotetext{
${ }^{16}$ Most of the data come from Miklukho-Maklaya Institute (1964), as reported in Taylor and Hudson (1972, table 4.15). See Mauro (1995) for a discussion.
} 
nance of the rule of law (also referred to as "law and order tradition"). The various time series cover 1982-97 and are available for a fee from Political Risk Services of Syracuse, New York. The general idea of these indexes is to gauge the attractiveness of a country's investment climate by considering the effectiveness of law enforcement, the sanctity of contracts, and the state of other influences on the security of property rights. Although these data are subjective, they have the virtue of being prepared contemporaneously by local experts. Moreover, the willingness of customers to pay substantial amounts for this information is perhaps some testament to their validity.

Among the various series available, the indicator for overall maintenance of the rule of $\operatorname{law}^{17}$ seemed a priori to be the most relevant for investment and growth. My previous empirical work (Barro 1997) confirms that this indicator is an important predictor of economic growth.

The connection between democracy and property rights is unclear, as stressed by Sirowy and Inkeles (1990) and Przeworski and Limongi (1993). The simple correlations between the electoral rights and rule-of-law indicators are .64 in 1982, .55 in 1985, .60 in 1990, and .49 in 1995. These correlations are much smaller than those between the electoral rights and civil liberties indexes (see below).

Regression 8 of table 3 checks out the relationship between electoral rights and the rule of law by entering lagged values of the ruleof-law index into the equations for democracy. Since the data on the rule of law begin in 1982, this system includes the equations for electoral rights for only 1985, 1990, and 1995. (The second lag of the dependent variable is excluded here.) The values for the rule of law in this system apply to 1982, 1985, and 1990. The result is that the estimated coefficient on the rule-of-law variable is positive but insignificant, $0.031(0.057)$. Thus, when the measures of standard of living are held fixed, there is not much timing evidence that better maintenance of the rule of law promotes electoral rights. (However, the rule of law can stimulate electoral rights indirectly by promoting economic growth.)

The rule-of-law measure can also be viewed as the dependent variable in a system in which the independent variables are its own lags and the lags of the other variables, including the electoral rights index. (Three equations-for 1985, 1990, and 1995-are used here.) In this setting, electoral rights turn out to enter with a positive

${ }^{17}$ The indicator was initially measured in seven categories on a zero to six scale, with six the most favorable. The scale has been revised here to zero to one, with zero indicating the worst maintenance of the rule of law and one the best. 
TABLE 4

Democracy in Relation to Colonial Status and Religion

A. Colonial Status

\begin{tabular}{lcc}
\hline \hline Colonial Status & $\begin{array}{c}\text { Number of } \\
\text { Countries }\end{array}$ & $\begin{array}{c}\text { Electoral } \\
\text { Rights Index* }\end{array}$ \\
\hline Noncolony & 32 & .69 \\
Colony & 106 & .46 \\
British colony & 53 & .54 \\
French colony & 23 & .26 \\
Spanish colony & 16 & .60 \\
Portuguese colony & 5 & .30 \\
Other colony & 9 & .36 \\
All countries & 138 & .52 \\
\hline
\end{tabular}

B. Religious AfFiLiation

\begin{tabular}{lcc}
\hline \hline $\begin{array}{c}\text { Primary Religious Affiliation } \\
\text { in 1980 }\end{array}$ & $\begin{array}{c}\text { Number of } \\
\text { Countries }\end{array}$ & $\begin{array}{c}\text { Electoral } \\
\text { Rights Index* }\end{array}$ \\
\hline Catholic & 53 & .60 \\
Muslim & 32 & .26 \\
Protestant & 21 & .80 \\
Hindu & 5 & .66 \\
Buddhist & 4 & .56 \\
Miscellaneous eastern religions & 3 & .46 \\
Jewish & 1 & .86 \\
Nonreligion & 1 & .10 \\
Other religion & 16 & .30 \\
All countries with data on religion & 136 & .51 \\
\hline
\end{tabular}

\footnotetext{
Note.-See the discussion in the text and table 3 for definitions of colonial status and religious affiliation. Panel B shows averages for 1975-95 of the electoral rights index for groups of countries in which the most common religious affiliation in 1980 is of the indicated type.

* Average for 1975-95.
}

coefficient, 0.023 (0.026), which is not statistically significant. Thus there is also not strong timing evidence that electoral rights stimulate the maintenance of the rule of law. Overall, the results indicate that, for given measures of the standard of living, there is a lot of independence in the ways electoral rights and the rule of law evolve.

\section{F. Colonial History}

Colonial heritage would be important for democracy if countries inherited tendencies for more or less political freedom from their previous rulers. For example, Lipset et al. (1993, p. 168) argue that British rule provided a crucial learning experience for subsequent democracy. In table 4, a noncolony is defined to be a country that was independent since 1775 (so that the United States is treated as a former possession of Britain). Each former colony is attributed to its most recent occupier; for example, the Philippines is associated 
with the United States rather than with Spain, Rwanda and Burundi are attached to Belgium rather than to Germany, and several Caribbean countries are related to Britain rather than to Spain. The classification treats as noncolonies places such as South Korea, Taiwan, Hungary, and Poland, which were occupied by a foreign power for some periods.

Panel A of table 4 shows that the 32 noncolonies are more likely to be democratic (average value for the electoral rights indicator from 1975 to 1995 of 0.69 ) than the colonies (average value of 0.46 ). Within the colonies, the former possessions of Britain and Spain are substantially more democratic than those of France, Portugal, and other countries. (The former Spanish colonies in Latin America would, however, look less democratic at some earlier dates.)

In the statistical analysis, with the measures of standard of living held constant, regression 9 of table 3 shows that a dummy variable for colonial status (one for former colony, zero for noncolony) is negative but statistically insignificant, $-0.018(0.018)$. Moreover, regression 10 shows that a breakdown among British, French, Spanish, Portuguese, and other colonies fails to generate any significant coefficients. The $p$-value for joint significance of the five colony dummies is .33. These results, in conjunction with table 4 , suggest that the influence of former colonial status on democratic tendency mostly works indirectly through effects on the standard of living, as measured here particularly by per capita GDP and primary schooling. These indirect links with colonial history are worth further study.

\section{G. Religion}

Religious affiliation has also been stressed as an important determinant of democracy (see Huntington 1991, pp. 71-85; Lipset 1994, p. 5; Boone 1996, pp. 25-28). Unfortunately, however, the theory of the interplay between religion and political structure is even less developed than other aspects of the theory of democracy.

To check for a connection between religion and political freedom, I use data compiled by Jong Wha Lee on the fractions of a country's population in 1970 and 1980 affiliated with nine major groups: ${ }^{18}$ Catholic (including Eastern Orthodox), Muslim, Protes-

${ }^{18}$ The underlying data, from the World Christian Encyclopedia (Barrett 1982), are estimates of professed affiliation in 1970 and 1980. (Figures are also available for 1900.) This information takes no account of regularity of church attendance or amounts spent on religious activities. The data provided in the encyclopedia are compiled from the most authoritative local sources, published or unpublished, including government censuses of religion. A large part of the data was collected directly by the editors, who visited virtually all the countries over the years 1965-75. The basic concept of a religious adherent is that the person professes to believe in the religion when government censuses or public opinion polls ask the question 
tant (including Anglican and some other Christian groups), Hindu (including Jains and Sikhs), Buddhist, miscellaneous eastern religions (Chinese folk religions, Shinto, Confucianism, and newreligionists), Jewish, no professed religion (including atheists), and other religious groups (such as Parsis, Bahais, Spiritists, tribal religions, and indigenous third-world Christians).

Panel B of table 4 verifies that differences in a country's primary religious affiliation relate strongly to democracy. When countries are sorted in accordance with their most popular religion in 1980, the average of the electoral rights indicator from 1975 to 1995 is 0.86 for Jewish (1 country), 0.80 for Protestant (21 countries), 0.66 for Hindu ( 5 countries), 0.60 for Catholic (53 countries), 0.56 for Buddhist ( 4 countries), 0.46 for miscellaneous eastern relgions ( 3 countries), 0.30 for other religions (16 countries), and 0.26 for Muslim (32 countries). China is the only place in which nonreligion is the most common affiliation, and the average of the electoral rights index in this case is 0.10 . The mean value of electoral rights for all 136 countries with data on religion is 0.51 .

A prominent aspect of this breakdown is that Protestant countries are nearly always highly democratic, whereas Muslim countries are usually not democratic. Only four of the 32 Muslim countries have electoral rights indicators that averaged at least 0.5 for 1975-95: Gambia (0.70), Senegal (0.50), Malaysia (0.57), and Turkey (0.62).

Regression 11 of table 3 shows the results when eight religious variables are entered into the equations for electoral rights. ${ }^{19}$ (The omitted characteristic is chosen arbitrarily to be Catholic, the most prevalent religion when countries are weighted equally.) The regressions indicate that the religion variables with the most significant coefficients are Muslim, -0.093 (0.026); nonreligion, -0.24 (0.09); and other religion, $-0.103(0.050)$.

The $p$-value of .002 indicates that the eight religion coefficients are significant overall. However, some of this significance hinges on the presence of a few outlier observations. For example, the positive coefficient on Hindu mainly indicates that India and Mauritius are surprisingly democratic, given their indicators of the standard of living. If these two places are omitted from the sample, then the esti-

\footnotetext{
"What is your religion?"' Each person is considered to have at most one religious affiliation. Further work on cross-country religion data is ongoing.

${ }^{19}$ The system allows for variation over time in religious affiliation in that the 1970 religion figures appear in the first three equations for democracy, and the 1980 figures enter into the last three equations. However, in most cases, the variations in religious affiliation between 1970 and 1980 are minor. If the 1970 values are included in all six equations, then the results are virtually indistinguishable from those shown in regression 11 of table 3 .
} 
mated coefficient on Hindu falls to -0.003 (0.062). The significance of the estimated coefficient on nonreligion-though not the point estimate-depends on the inclusion of China, the one country for which this affiliation exceeds $0.5 .{ }^{20}$ If China is omitted, then this coefficient becomes $-0.24(0.13)$.

Probably the most interesting finding is the significantly negative coefficient on the Muslim variable, even when the measures of standard of living and the other explanatory variables are held constant. The estimated coefficient of -0.093 means that, for given values of the other explanatory variables, the long-run level of electoral rights is lower by 0.32 - about two Freedom House categories-in a Muslim country (as compared to the benchmark of a Catholic country). Possibly this result reflects the strong linkage between church and state in many Muslim countries.

The estimated coefficients understate the potential consequence of religion for democracy because of the potential effects of religion on some of the explanatory variables, especially the gap between male and female education and the indicators of the standard of living. In fact, the main effects of religion on democracy are likely to work through these indirect channels. Given the striking patterns that emerge in table 4, these linkages are worth further investigation.

\section{Civil Liberties}

The electoral rights indicator is a narrow procedural measure that focuses on the role of elections. In contrast, the Freedom House index of civil liberties is a broader concept that covers freedoms of speech, press, and religion and also considers a variety of legal protections. In practice, however, the civil liberties variable is highly correlated with the electoral rights index: .86 in 1972, .93 in 1980, .94 in 1990, and .92 in 1995 .

Given this high degree of correlation, it is not surprising that results with the civil liberties index as the dependent variable-shown in column 2 of table 1-look similar to those found for the electoral rights index. ${ }^{21}$ This result suggests that the economic and social forces that promote electoral rights are similar to those that stimulate civil liberties.

${ }^{20}$ The 1980 value of nonreligion for China is 0.71 . The other values that exceed 0.1 are 0.35 for Uruguay; 0.29 for Sweden; 0.17 for Yugoslavia; 0.16 for Italy, Hungary, and France; 0.15 for Australia; 0.14 for Hong Kong; and 0.12 for the Netherlands and Japan.

${ }^{21}$ A formal test rejects equality of the coefficients in the systems for electoral rights and civil liberties. Viewed individually, however, the only estimated coefficients that are found to differ significantly at the 5 percent critical level are those for the lagged dependent variables, $\log$ of population, and the constant terms. 


\section{Long-Run Forecasts of Democracy}

The estimated relation from column 1 of table 1 implies a gradual adjustment of democracy - as measured by electoral rights-toward the values determined by the explanatory variables aside from lagged democracy. ${ }^{22}$ In a full system, the dynamics of these explanatory variables would also be determined. In practice, the level of per capita GDP and the other variables are highly persistent over time, although they evolve gradually in line with the process of economic development, some of which has been studied in previous research in terms of rates of economic growth.

One simple way to relate the current level of democracy to its long-run target is to compute at each date the estimated level of democracy that would arise asymptotically if all the right-hand-side variables (aside from the lagged dependent variables) were held fixed at their current values. For example, in 1975, the long-run level of the electoral rights index is calculated from the 1970 values of the regressors included in column 1 of table $1 .^{23}$ The resulting projected values for 1975 and 1995 are shown along with the actual values in table 5 . The gap is the difference between the current level of electoral rights and its long-run target. Values of the gap that exceed 0.33 in magnitude are shown in boldface.

In 1975 , out of 101 countries with the necessary data, five were below the long-run target for electoral rights by at least 0.33 and 21 were above by at least 0.33 . In 1995 , out of 100 places with the required data, 16 were below target by at least 0.33 , and five were above target by at least 0.33 .

One striking observation is that no country appears with the same sign on both lists (although Yugoslavia comes close). With an estimated rate of convergence for electoral rights of about one-quarter per five-year period (from the coefficients on the lags of the dependent variable in col. 1 of table 1 ), a lot of reversion to the mean occurs over 20 years.

Among the sub-Saharan African countries, Botswana, Gambia, and Mauritius (if Mauritius is classed with Africa) looked "too democratic" in 1975, but the situation for Gambia changed with a coup in 1994. Botswana and Mauritius were still above target for democracy in 1995, but by much smaller amounts than in 1975 .

\footnotetext{
${ }^{22}$ More precisely, the model shows how initial electoral rights and the values of the other explanatory variables influence the probabilities of transition over time among the seven discrete rankings of electoral rights.

${ }^{23}$ The projected value equals $[1 /(1-$ coefficient of first lag of electoral rights coefficient of second lag of electoral rights) $] \times$ (estimated value based on explanatory variables other than the lagged dependent variables).
} 
A surge of democratization since the late 1980s meant that many of the countries in sub-Saharan Africa became more democratic than predicted by 1995. This group includes Benin, Central African Republic, Guinea-Bissau, Malawi, Mali, Niger, and Zambia. In some of these cases, the democratization may be explicable from the pressures and rewards exerted by international organizations, such as the IMF and the World Bank. (The recent U.S. efforts in Haiti are analogous.) In any case, the regression analysis predicts that, as with the African experience of the 1960s, democracy that gets well ahead of economic development will not last. As a possible indicator of this process, Niger had a military coup in January 1996 and then became nondemocratic.

Some sub-Saharan African countries still had below-target levels of democracy in 1995. Prominent here are Cameroon, Kenya, Rwanda, Sierra Leone, Sudan, and Swaziland. (Nigeria and Somalia would likely be included in this category but have missing data and are therefore excluded from table 5.)

For Latin America in 1975, several countries were surprisingly nondemocratic, including Panama, Chile, and Ecuador. All these places subsequently experienced sharp increases in electoral rights. In 1995, Bolivia had more democracy than would be predicted from its economic situation. Mexico and Peru were below target in 1995 and were predicted to become more democratic.

Among Asian countries, surprisingly low democracy prevailed in 1995 in China, Hong Kong, Indonesia, Singapore, and Syria. The model predicts increases in democracy in these cases, but the model has not been informed of Hong Kong's post-July 1997 relationship with China. It will be especially interesting to see whether prosperous Singapore joins South Korea and Taiwan in their marked democratizations.

On the other side, democracy was higher than predicted in 1975 for India, Indonesia, Malaysia, Sri Lanka, and Thailand. However, with the decline in the Freedom House measure of electoral rights in 1991 and 1993, India no longer looked like an outlier in 1995. Indonesia, Malaysia, Sri Lanka, and Thailand were all below target in 1995 .

Because of lack of data, only three countries from central or eastern Europe are represented in the sample: Hungary, Poland, and Yugoslavia. In each of these cases, democracy was strikingly below its target level in 1975. Two countries in western Europe-Portugal and Spain-were also below target. By 1995, all these countries except Yugoslavia had-as predicted-become far more democratic. The model forecasts a large increase of democracy in Yugoslavia, which should perhaps now be identified with Serbia. The model also 
TABLE 5

Actual and Long-Run Values of Democracy

\begin{tabular}{|c|c|c|c|c|c|c|}
\hline \multirow[b]{2}{*}{ COUntry } & \multicolumn{3}{|c|}{ DEMOCRACY 1975} & \multicolumn{3}{|c|}{ DEMOCRACY 1995} \\
\hline & Actual & Projected & Gap & Actual & Projected & Gap \\
\hline Algeria & .17 & $(-.14)$ & $(.31)$ & .17 & .26 & -.09 \\
\hline Benin & .00 & .23 & -.23 & .83 & .36 & .47 \\
\hline Botswana & .83 & .26 & .57 & .83 & .75 & .09 \\
\hline Cameroon & .17 & .08 & .08 & .00 & .44 & -.44 \\
\hline Central African Republic & .00 & .03 & -.03 & .67 & .21 & .45 \\
\hline Congo & .33 & $\ldots$ & $\ldots$ & .50 & .56 & -.06 \\
\hline Egypt & .17 & $.15^{*}$ & .01 & .17 & .48 & -.31 \\
\hline Gambia & .83 & $.06 *$ & .78 & .00 & .33 & -.33 \\
\hline Ghana & .00 & .09 & -.09 & .50 & .33 & .17 \\
\hline Guinea-Bissau & .17 & $\ldots$ & $\ldots$ & .67 & $.33 * *$ & .33 \\
\hline Kenya & .33 & .04 & .30 & .00 & .40 & -.40 \\
\hline Lesotho & .33 & .32 & .01 & .50 & .81 & -.31 \\
\hline Liberia & .17 & .08 & .09 & .00 & $\ldots$ & $\ldots$ \\
\hline Malawi & .00 & $(-.03)$ & $(.03)$ & .83 & .28 & .55 \\
\hline Mali & .00 & .03 & -.03 & .83 & .34 & .49 \\
\hline Mauritius & .83 & .20 & .63 & 1.00 & .79 & .21 \\
\hline Mozambique & .17 & .33 & -.17 & .67 & .40 & .27 \\
\hline Niger & .00 & .19 & -.19 & .67 & .36 & .31 \\
\hline Rwanda & .00 & .19 & -.19 & .00 & .39 & -.39 \\
\hline Senegal & .17 & .14 & .03 & .50 & .44 & .06 \\
\hline Sierra Leone & .17 & .20 & -.03 & .00 & .38 & -.38 \\
\hline South Africa & .50 & .55 & -.05 & 1.00 & .78 & .22 \\
\hline Sudan & .17 & .22 & -.06 & .00 & .47 & -.47 \\
\hline Swaziland & .17 & .37 & -.20 & .17 & .65 & -.48 \\
\hline Tanzania & .17 & $.08 * *$ & .09 & .33 & $.33^{* *}$ & .00 \\
\hline Togo & .00 & .06 & -.06 & .17 & .22 & -.05 \\
\hline Tunisia & .17 & .14 & .03 & .17 & .53 & -.37 \\
\hline Uganda & .00 & .10 & -.10 & .33 & .34 & -.01 \\
\hline Zaire & .00 & $(-.01)$ & $(.01)$ & .00 & .16 & -.16 \\
\hline Zambia & .33 & .01 & .32 & .67 & .16 & .51 \\
\hline Zimbabwe & .17 & .18 & -.02 & .33 & .49 & -.15 \\
\hline Barbados & 1.00 & .65 & .35 & 1.00 & 1.00 & .00 \\
\hline Canada & 1.00 & .82 & .18 & 1.00 & $(1.23)$ & $(-.23)$ \\
\hline Costa Rica & 1.00 & .49 & .51 & 1.00 & .85 & .15 \\
\hline Dominican Republic & .50 & .31 & .19 & .50 & .62 & -.12 \\
\hline El Salvador & .83 & .21 & .62 & .67 & .62 & .05 \\
\hline Guatemala & .50 & .32 & .18 & .50 & .66 & -.16 \\
\hline Haiti & .17 & .16 & .01 & .33 & .28 & .06 \\
\hline Honduras & .17 & .27 & -.11 & .67 & .62 & .04 \\
\hline Jamaica & 1.00 & .49 & .51 & .83 & .75 & .08 \\
\hline Mexico & .50 & .32 & .18 & .50 & .89 & -.39 \\
\hline Nicaragua & .33 & .35 & -.02 & .50 & .49 & .01 \\
\hline Panama & .00 & .44 & -.44 & .83 & .82 & .01 \\
\hline Trinidad and Tobago & .83 & .64 & .20 & 1.00 & .96 & .04 \\
\hline United States & 1.00 & .95 & .05 & 1.00 & $(1.30)$ & $(-.30)$ \\
\hline Argentina & .50 & .57 & -.07 & .83 & .87 & -.04 \\
\hline Bolivia & .17 & .15 & .02 & .83 & .51 & .32 \\
\hline Brazil & .50 & .43 & .07 & .83 & .82 & .01 \\
\hline Chile & .00 & .49 & -.49 & .83 & .79 & .04 \\
\hline Colombia & .83 & .36 & .48 & .50 & .82 & -.32 \\
\hline Ecuador & .00 & .36 & -.36 & .83 & .76 & .08 \\
\hline Guyana & .50 & .40 & .10 & .83 & .66 & .17 \\
\hline Paraguay & .33 & .30 & .04 & .50 & .71 & -.21 \\
\hline Peru & .17 & .29 & -.12 & .33 & .61 & -.28 \\
\hline
\end{tabular}


TABLE 5 (Continued)

\begin{tabular}{|c|c|c|c|c|c|c|}
\hline \multirow[b]{2}{*}{ COUNTRY } & \multicolumn{3}{|c|}{ Democracy 1975} & \multicolumn{3}{|c|}{ DEMOCRACY 1995} \\
\hline & Actual & Projected & Gap & Actual & Projected & Gap \\
\hline Uruguay & .33 & .50 & -.17 & .83 & .82 & .02 \\
\hline Venezuela & .83 & .21 & .62 & .67 & .51 & .15 \\
\hline Bahrain & .17 & $\ldots$ & $\ldots$ & .17 & .47 & -.30 \\
\hline Bangladesh & .00 & .25 & -.25 & .67 & .55 & .11 \\
\hline China & .00 & $.12 *$ & -.12 & .00 & .54 & -.54 \\
\hline Hong Kong & .67 & .12 & .54 & .50 & .92 & -.42 \\
\hline India & .83 & .10 & .74 & .50 & .48 & .02 \\
\hline Indonesia & .33 & $(-.19)$ & $(.53)$ & .00 & .38 & -.38 \\
\hline Iran & .17 & .11 & .06 & .17 & .31 & -.14 \\
\hline Iraq & .00 & .05 & -.05 & .00 & .04 & -.04 \\
\hline Israel & .83 & .50 & .33 & 1.00 & .96 & .04 \\
\hline Japan & .83 & .76 & .07 & 1.00 & $(1.21)$ & $(-.21)$ \\
\hline Jordan & .17 & .02 & .14 & .50 & .45 & .05 \\
\hline South Korea & .33 & .25 & .08 & .83 & .94 & -.10 \\
\hline Malaysia & .67 & .13 & .53 & .50 & .77 & -.27 \\
\hline Nepal & .17 & .22 & -.05 & .67 & .45 & .22 \\
\hline Pakistan & .33 & .16 & .17 & .67 & .50 & .17 \\
\hline Philippines & .33 & .44 & -.11 & .83 & .86 & -.03 \\
\hline Singapore & .33 & .01 & .32 & .33 & .79 & -.45 \\
\hline Sri Lanka & .83 & .30 & .54 & .50 & .81 & -.31 \\
\hline Syria & .17 & .13 & .04 & .00 & .57 & -.57 \\
\hline Taiwan & .17 & .25 & -.08 & .67 & .96 & -.30 \\
\hline Thailand & .83 & .35 & .48 & .67 & .95 & -.28 \\
\hline Austria & 1.00 & .68 & .32 & 1.00 & $(1.07)$ & $(-.07)$ \\
\hline Belgium & 1.00 & .83 & .17 & 1.00 & (1.16) & $(-.16)$ \\
\hline Cyprus & .50 & .36 & .14 & 1.00 & .93 & .07 \\
\hline Denmark & 1.00 & .83 & .17 & 1.00 & $(1.20)$ & $(-.20)$ \\
\hline Finland & .83 & .93 & -.10 & 1.00 & $(1.30)$ & $(-.30)$ \\
\hline France & 1.00 & .76 & .24 & 1.00 & (1.12) & $(-.12)$ \\
\hline West Germany & 1.00 & .91 & .09 & 1.00 & (1.26) & $(-.26)$ \\
\hline Greece & .83 & .45 & .38 & 1.00 & .79 & .21 \\
\hline Hungary & .17 & .80 & -.64 & 1.00 & (1.01) & $(-.01)$ \\
\hline Iceland & 1.00 & .56 & .44 & 1.00 & .97 & .03 \\
\hline Ireland & 1.00 & .68 & .32 & 1.00 & $(1.10)$ & $(-.10)$ \\
\hline Italy & 1.00 & .70 & .30 & 1.00 & $(1.05)$ & $(-.05)$ \\
\hline Malta & 1.00 & .30 & .70 & 1.00 & $\ldots$ & $\ldots$ \\
\hline Netherlands & 1.00 & .75 & .25 & 1.00 & (1.09) & $(-.09)$ \\
\hline Norway & 1.00 & .80 & .20 & 1.00 & (1.12) & $(-.12)$ \\
\hline Poland & .17 & .62 & -.46 & 1.00 & $(1.04)$ & $(-.04)$ \\
\hline Portugal & .33 & .44 & -.10 & 1.00 & .94 & .06 \\
\hline Spain & .33 & .61 & -.27 & 1.00 & $(1.06)$ & $(-.06)$ \\
\hline Sweden & .83 & .70 & .13 & 1.00 & $(1.11)$ & $(-.11)$ \\
\hline Switzerland & 1.00 & .86 & .14 & 1.00 & $(1.20)$ & $(-.20)$ \\
\hline Turkey & .67 & .28 & .39 & .33 & .75 & -.42 \\
\hline United Kingdom & 1.00 & .77 & .23 & 1.00 & $(1.19)$ & $(-.19)$ \\
\hline Yugoslavia & .17 & .44 & -.27 & .17 & .81 & -.64 \\
\hline Australia & 1.00 & .83 & .17 & 1.00 & (1.18) & $(-.18)$ \\
\hline Fiji & .83 & .33 & .50 & .50 & .83 & -.33 \\
\hline New Zealand & 1.00 & .81 & .19 & 1.00 & (1.13) & $(-.13)$ \\
\hline Papua New Guinea & .67 & .34 & .33 & .83 & .54 & .29 \\
\hline
\end{tabular}

Note.-Actual values pertain to the electoral rights index. Projected values are based on the estimated system shown in table 1 , col. 1 . The 1975 projection is $[1 /(1-$ coefficient of first lag of electoral rights coefficient of second lag of electoral rights) $] \times$ (estimated value based on explanatory variables other than the lagged dependent variables included in the 1975 equation). The 1995 projection is formed analogously. Values in parentheses are linearly fitted values that lie outside the range $(0,1)$. Values shown in bold have a magnitude of at least .33 .

* Projected value for 1975 uses 1975 schooling values because of missing data for 1970

** Projected value based on estimated schooling value for persons aged 25 and over based on available data for persons aged 15 and over. 
predicts substantial democratization for Turkey, which was surprisingly nondemocratic in 1995.

\section{Concluding Observations}

The data for a large panel of countries confirm the Lipset/Aristotle hypothesis, which says that a higher standard of living promotes democracy. This relation shows up when democracy is represented by electoral rights or civil liberties and when the standard of living is measured by per capita GDP, primary school attainment, the gap between male and female primary schooling (which enters negatively), and the importance of the middle class. Democracy does not relate significantly to school attainment at the secondary and higher levels. For a given standard of living, democracy tends to fall with urbanization and a greater reliance on natural resources but has little relation to country size.

The apparently strong relation of democracy to colonial heritage mostly disappears when the measures of standard of living are held constant. Similarly, the allowance for standard of living weakens the interplay between democracy and religious affiliation. However, negative effects from Muslim and non-religious affiliations remain intact.

Given the strength of the Lipset/Aristotle hypothesis as an empirical regularity, it is surprising that convincing theoretical models of the relation do not exist. Thus development of such a theory is a priority for future research.

At an empirical level, it would be especially interesting to investigate further the relation of democracy to inequality, colonial status, and religion. Hopefully, the development of satisfactory theories of the determination of democracy will suggest additional empirical linkages that ought to be explored.

\section{References}

Alesina, Alberto, and Spolaore, Enrico. "On the Number and Size of Nations." Manuscript. Cambridge, Mass.: Harvard Univ., October 1995.

Aristotle. Politics. Translated by H. Rackham. Cambridge, Mass.: Harvard Univ. Press, 1932.

Barrett, David B., ed. World Christian Encyclopedia: A Comparative Study of Churches and Religions in the Modern World, AD 1900-2000. Oxford: Oxford Univ. Press, 1982.

Barro, Robert J. Determinants of Economic Growth: A Cross-Country Empirical Study. Cambridge, Mass.: MIT Press, 1997.

Barro, Robert J., and Lee, Jong Wha. "International Measures of Schooling Years and Schooling Quality.' A.E.R. Papers and Proc. 86 (May 1996): 21823.

Bollen, Kenneth A. "Political Democracy: Conceptual and Measurement Traps." Studies Comparative Internat. Development 25 (Spring 1990): 7-24. 
Boone, Peter. "Political and Gender Oppression as a Cause of Poverty." Manuscript. London: London School Econ., April 1996.

Deininger, Klaus, and Squire, Lyn. "Measuring Income Inequality: A New Data-Base." Manuscript. Washington: World Bank, March 1996.

Gastil, Raymond D. Freedom in the World. Westport, Conn.: Greenwood, various years.

- "The Comparative Survey of Freedom: Experiences and Suggestions." On Measuring Democracy: Its Consequences and Concomitants, edited by Alex Inkeles. New Brunswick, N.J.: Transaction, 1991.

Huber, Evelyne; Rueschemeyer, Dietrich; and Stephens, John D. "The Impact of Economic Development on Democracy." J. Econ. Perspectives 7 (Summer 1993): 71-85.

Huntington, Samuel P. The Third Wave: Democratization in the Late Twentieth Century. Norman: Univ. Oklahoma Press, 1991.

Inkeles, Alex, ed. On Measuring Democracy: Its Consequences and Concomitants. New Brunswick, N.J.: Transaction, 1991.

Knack, Stephen, and Keefer, Philip. "Institutions and Economic Performance: Cross-Country Tests Using Alternative Institutional Measures.' Econ. and Politics 7 (November 1995): 207-27.

Lipset, Seymour Martin. "Some Social Requisites of Democracy: Economic Development and Political Legitimacy." American Polit. Sci. Rev. 53 (March 1959): 69-105.

_. "The Social Requisites of Democracy Revisited: 1993 Presidential Address." American Sociological Rev. 59 (February 1994): 1-22.

Lipset, Seymour Martin; Seong, Kyoung-Ryung; and Torres, John Charles. "A Comparative Analysis of the Social Requisites of Democracy." Internat. Soc. Sci. J. 45 (May 1993): 155-75.

Mauro, Paolo. "Corruption and Growth.” Q.J.E. 110 (August 1995): 681-712.

Miklukho-Maklaya Institute of Ethnography of the Academy of Sciences. Atlas Narodov Mira. Moscow: Dept. Geodesy and Cartography, State Geological Comm. USSR, 1964.

Przeworski, Adam, and Limongi, Fernando. "Political Regimes and Economic Growth." J. Econ. Perspectives 7 (Summer 1993): 51-69.

Putnam, Robert D. Making Democracy Work: Civic Traditions in Modern Italy. Princeton, N.J.: Princeton Univ. Press, 1993.

Sachs, Jeffrey D., and Warner, Andrew M. "Natural Resource Abundance and Economic Growth.” Manuscript. Cambridge, Mass.: Harvard Inst. Internat. Development, December 1995.

Schumpeter, Joseph A. Capitalism, Socialism, and Democracy. 2d ed. New York: Harper, 1947.

Sirowy, Larry, and Inkeles, Alex. "The Effects of Democracy on Economic Growth and Inequality: A Review.' Studies Comparative Internat. Development 25 (Spring 1990): 126-57.

Summers, Robert, and Heston, Alan. "The Penn World Table (Mark 5): An Expanded Set of International Comparisons, 1950-1988.” Q.J.E. 106 (May 1991): 327-68.

—_. "Penn World Tables, Version 5.6." Cambridge, Mass.: NBER, 1995. www.nber.org.

Taylor, Charles Lewis, and Hudson, Michael C. World Handbook of Political and Social Indicators. 2d ed. New Haven, Conn.: Yale Univ. Press, 1972.

Tocqueville, Alexis de. Democracy in America. Translated by Henry Reeve. London: Saunders \& Otley, 1835. 